\title{
Serum levels of inhibitors of wingless / beta-catenin in patients with ankylosing spondylitis and the relationship with anti-tumour necrosis factor alpha treatments
}

\section{Ankilozan spondilit hastalarında wingless / beta-katenin inhibitörlerinin} serum düzeyi ve anti-tümör nekrozis faktör alfa tedavileri ile ilişkisi

\author{
Ahmet Akyol ${ }^{1 *}(\mathbb{D})$, Burhan Fatih Koçyiğit ${ }^{2}$ (D) Osman Konukoğlu ${ }^{3}$ (D), Ali Gür ${ }^{4}\left(\mathbb{D}\right.$, Özlem Altındağ ${ }^{4}$ (D), \\ Ali Aydeniz ${ }^{4}$ (D) , Müzeyyen Günay Örkmez ${ }^{5}$ (D), Mehmet Tarakçıoğlu ${ }^{6}$ (D), Hasan Ulusal ${ }^{6}$ (D), \\ Savaş Gürsoy ${ }^{4}$ (iD \\ ${ }^{1}$ Nizip State Hospital, Department of Physical Medicine and Rehabilitation, Gaziantep, Turkey \\ ${ }^{2}$ Kahramanmaras Sütçü İmam University, Faculty of Medicine, Department of Physical Medicine and Rehabilitation, Kahramanmaras, \\ Turkey \\ ${ }^{3}$ Şanlıurfa Mehmet Akif İnan Training and Research Hospital Department of Radiology, Şanlıurfa, Turkey \\ ${ }^{4}$ Gaziantep University, Faculty of Medicine, Department of Physical Medicine and Rehabilitation, Gaziantep, Turkey \\ ${ }^{5} 25$ Aralık State Hospital, Department of Physical Medicine and Rehabilitation, Gaziantep, Turkey \\ ${ }^{6}$ Gaziantep University, Faculty of Medicine, Department of Biochemistry, Gaziantep, Turkey \\ * Corresponding author: Ahmet Akyol E-mail: ahmetakyol07@gmail.com ORCID: 0000-0002-8953-5196 \\ Received: 30 July 2018 Accepted: 24 September 2018
}

\begin{abstract}
Aim: The primary aim of the study was to compare the serum levels of Dickkopf-1 (DKK-1) and sclerostin in patients with ankylosing spondylitis (AS) and healthy controls. The secondary aim was to evaluate the effects of anti-tumor necrosis factor alpha (TNF-a) treatments on levels of DKK-1 and sclerostin. The last aim was to evaluate any relationship between DKK-1, sclerostin, and radiologic progression in AS.

Material and Method: We included 70 patients with AS (35 anti-TNF-a treated, 35 anti-TNF-a naïve) and 31 healthy controls in this study. Serum DKK-1, sclerostin, C reactive protein, and erythrocyte sedimentation rate (ESR) were assessed in patients and healthy controls. The Ankylosing Spondylitis Disease Activity Score (ASDAS), Bath Ankylosing Spondylitis Disease Activity Index (BASDAI), Bath Ankylosing Spondylitis Metrology Index (BASMI), and Bath Ankylosing Spondylitis Functional Index (BASFI) were calculated for the patients. Radiographs were scored according to the modified Stoke AS Spine Score (mSASSS) by an experienced radiologist who was blinded to the patients' identity.
\end{abstract}

( 2019 by the authors; licensee MEDITAGEM Ltd., Turkey. This article is an open access article distributed under the terms and conditions of the Creative Commons Attribution License (http://creativecommons.org/licenses/by/4.0/). 
Results: Patients with AS who were treated with anti-TNF-a agent had higher scores of BASMI and mSASSS compared with the anti-TNF-a naïve patients. Serum levels of DKK-1 and sclerostin were significantly lower in patients with AS than in healthy controls. There was a negative correlation between DKK-1 levels with ASDAS and BASMI in patients with AS. There was no correlation between DKK-1 or sclerostin levels with mSASSS. There was a positive correlation between BASMI score with mSASSS in patients with AS.

Conclusion: DKK-1 levels in patients with AS were negatively correlated with BASMI, on the other hand, BASMI had a strong positive correlation with mSASSS. Therefore, these findings suggest that lower DKK-1 levels in patients with AS may play a role in new bone formation.

Keywords: ankylosing spondylitis, dickkopf-1, sclerostin, anti-tumor necrosis factor alpha

\section{öz}

Amaç: Bu çalışmadaki öncelikli amacımız ankilozan spondilit (AS) hastalarında ve sağlıklı kontrollerde Dickkopf-1 (DKK-1) ve sklerostinin serum düzeylerini karşılaştırmaktı. İkincil amacımız anti-tümör nekrozis faktör alfa (anti-TNF- $\alpha$ ) tedavilerinin DKK1 ve sklerostinin serum düzeylerine olan etkisini değerlendirmekti. Son olarak AS hastalarında DKK-1, sklerostin düzeyleri ile radyolojik progresyon arasında ilişki olup olmadığını değerlendirmeyi amaçladık.

Gereç ve Yöntem: Çalışmamıza 70 AS (35 anti-TNF tedavi alan, 35 anti-TNF almayan) hastası ve 31 sağlıklı kontrol alındı. Hastalarda ve sağlıklı kontrollerde serum DKK-1, sklerostin, C-reaktif protein ve eritrosit sedimentasyon hızı ölçüldü. Ankilozan spondilit hastalık aktivite skoru (ASDAS), Bath ankilozan spondilit hastalık aktivite indeksi (BASDAI), Bath ankilozan spondilit metroloji indeksi (BASMi), Bath ankilozan spondilit fonksiyonel indeksi (BASFi) hesaplandı. Radyografiler hasta bilgilerine körleştirilmiş deneyimli bir radyolog tarafından modifiye stoke ankilozan spondilit spinal skoru (mSASSS) yöntemine göre skorlandı.

Bulgular: Anti-TNF- $\alpha$ tedavi alan AS hastalarında BASMI ve mSASSS skorları anti-TNF- $\alpha$ tedavi almayan hastalara göre daha yüksekti. AS hastalarında serum DKK-1 ve sklerostin düzeyleri sağlıklı kontrollere göre daha düşüktü. AS hastalarında DKK-1 düzeyleri ile ASDAS ve BASMi arasında ters yönlü bir korelasyon vardı. DKK-1 ve sklerostin düzeyleri ile mSASSS arasında korelasyon yoktu. AS hastalarında BASMi skoru ile mSASSS arasında anlamlı korelasyon vardı.

Sonuç: AS hastalarındaki DKK-1 düzeyleri ile BASMI arasında ters yönlü bir korelasyon vardı, diğer yandan BASMI ve mSASSS skorları arasında güçlü bir korelasyon vardı. Bu nedenler, bu bulgular AS hastalarındaki düşük DKK-1 seviyelerinin yeni kemik oluşumunda rol oynayabileceğini düşündürmektedir.

Anahtar kelimeler: ankilozan spondilit, Dickkopf-1, sklerostin, anti-tümör nekrozis faktör alfa

\section{INTRODUCTION}

Ankylosing spondylitis (AS) is a chronic inflammatory disease that predominantly affects the sacroiliac joints and intervertebral spaces, and is characterized by back pain, stiffness, enthesitis, peripheral arthritis, new bone formation, syndesmophytes, and ankylosis [1]. Progressive new bone formation may result in a bamboo formation of the spine and spinal limitations in patients with AS [2]. Nonsteroidal anti-inflammatory drugs and tumor necrosis factor alpha (TNF-a) antagonists, which reduce the signs and symptoms associated with AS, may not be able to completely inhibit the radiologic progression of the disease $[3,4]$. Despite the suppression of inflammation with TNF-a antagonists, different results have been obtained in the prevention of radiologic progression. Therefore, different parameters and mechanisms beside inflammation may play a role in this process. The most controversial hypothesis is the possible increase in the Wingless / Integrated / $\beta$-catenin (Wnt / $\beta$-catenin) pathway in patients with AS [5]. Studies have been demonstrated that excessive Wnt / $\beta$-catenin signaling stimulates osteoblastogenesis, new bone formation, and fibrosis in several tissues [6]. Dickkopf-1 (DKK-1) and sclerostin are major inhibitors of the Wnt/ $\beta$ catenin pathway. DKK-1 and sclerostin block Wnt signaling by binding to its co-receptors low-density lipoprotein receptor-related protein 5 (LRP5) and 6 (LRP6) [7]. In animal 
studies, increased levels of DKK-1 were found to be associated with bone resorption, whereas decreased levels were found to be associated with new bone formation [8]. Lower levels of DKK-1 are linked with new spinal bone formation in patients with diffuse skeletal hyperostosis [9].

Conflicting results have been observed in studies aiming to explore the link between DKK-1, sclerostin, and bone formation in AS [10-12]. Some studies declared elevated serum DKK-1 and sclerostin levels, others reported lower levels or similar levels in patients with AS. Thus, the aim of this study was to investigate the serum levels of DKK-1 and sclerostin in patients with AS and healthy controls. The secondary aim was to evaluate the effects of anti-TNF-a treatments on levels of DKK- 1 and sclerostin. The final aim was to evaluate any relationship between DKK-1, sclerostin, and structural damage in AS.

\section{MATERIAL AND METHOD}

This was a case-control study. A total of 70 patients with AS who presented to our hospital's Department of Physical Medicine and Rehabilitation-Rheumatology polyclinic between March 2015 and February 2016 and 31 healthy controls were evaluated in this study. The patients with AS included in this study fulfilled the modified New York criteria [13]. Patients were divided into two groups; the TNF-a inhibitör treated group $(n=35)$ and the TNF-a inhibitor naïve group ( $n=35)$. The study included $52(74 \%)$ male and 18 (26\%) female patients.

Exclusion criteria consisted of malignancy, diabetes mellitus, metabolic bone diseases, acute or chronic infection, inflammatory bowel disease, cardiac and renal disease, current bisphosphonates and glucocorticoid use, and pregnant and lactating women. The study was conducted in accordance with the Declaration of Helsinki and was approved by the local ethics committee (Approval number: 2015/66). This study received a grant from the Gaziantep University Scientific Research Project Unit (Project no: TF.15.34). Both patients and controls provided written informed consent.

Socio-demographic data were recorded, including age, sex, height, weight, body mass index (BMI), and disease duration.

Disease activity was evaluated using the Bath ankylosing spondylitis disease activity index (BASDAI) and ankylosing spondylitis disease activity index-CRP (ASDAS) [14,15]. A metrologic assessment was evaluated using the Bath ankylosing spondylitis metrology index (BASMI), and functional ability using the Bath ankylosing spondylitis functional index (BASFI) [16]. We measured radiologic changes using the Bath ankylosing spondylitis radiology index (BASRI) and modified stoke ankylosing spondylitis spinal score (mSASSS) [17,18]. Radiographs were scored by an experienced radiologist who was blinded to the patients' identity.

On the same day of the physical examination, blood samples were obtained from all subjects between $8.00-9.00$ AM after an overnight fast. C-reactive protein (CRP) (Cobas Integra 400 plus, Rotkreuz, Switzerland) and the erythrocyte sedimentation rate (ESR) (Eventus VacuPlus ESR 100, Ankara, Turkey) were analyzed using standard laboratory techniques.

\section{Measurement of DKK-1 and Sclerostin Levels}

Samples of peripheral blood were centrifuged at $4000 \mathrm{rpm}$ for 10 minutes, and serum was separated and stored at $80^{\circ} \mathrm{C}$. Total serum DKK-1 and sclerostin ( $\mathrm{ng} / \mathrm{mL}$ ) were measured using a commercial enzyme-linked immunosorbent assay (ELISA) (Sunred, Shangai, China) according to the manufacturer's recommendations.

\section{Statistical Analysis}

Statistical analysis was performed using the SPSS v.22.0 for Windows software package (SPSS, Inc., Chicago, IL). All results are expressed as mean and standard deviation and number. The distribution of data was assessed using Shapiro-Wilk test. The Chi-square test was performed in order to identify differences in categorical variables between groups. Comparisons of groups were evaluated using the independent sample t-test according to ShapiroWilk test results. Correlations between continuous variables were analyzed using Pearson's correlation test. $P$ values less than 0.05 were accepted as statistically significant.

\section{RESULTS}

The mean age was $42.46 \pm 11.14$ years, $41.46 \pm 10.82$ years, and 41.96 \pm 10.91 years for the TNF- $a$ inhibitör treated group, TNF-a inhibitör naïve group, and the control group, respectively $(p=0.712)$. The mean values of $B M I$ were $27.24 \pm 4.32 \mathrm{~kg} / \mathrm{m} 2$ in the patient group and $22.56 \pm 3.82$ $\mathrm{kg} / \mathrm{m} 2$ in the control group $(p=0.001)$. The mean disease duration was $12.2 \pm 6.36$ years and was not different between the treatment groups $(p=0.108)$. Demographic data are presented in Table 1.

The mean BASMI and mSASSS scores were significantly greater in the TNF- $a$ inhibitör treated group $(p=0.048$ and $p=0.024)$. There was no significant difference between the groups in terms of BASDAI, ASDAS, and BASFI scores ( $p>0.05$ ) (Table 2). 
Table 1. Demographic data of the ankylosing spondylitis patients and controls

\begin{tabular}{|c|c|c|c|}
\hline & $\begin{array}{c}\text { Ankylosing } \\
\text { spondylitis }\end{array}$ & Control & $\mathbf{p}$ \\
\hline Number of cases $(\mathrm{n})$ & 70 & 31 & - \\
\hline Age (year) & $39.32 \pm 6.79$ & $41.96 \pm 10.91$ & 0.06 \\
\hline Gender (female / male) & $18 / 52$ & $14 / 17$ & 0.01 \\
\hline $\mathrm{BMI}\left(\mathrm{kg} / \mathrm{m}^{2}\right.$ ) & $27.24 \pm 4.32$ & $22.56 \pm 3.82$ & 0.001 \\
\hline Disease duration (year) & $12.2 \pm 6.36$ & - & - \\
\hline
\end{tabular}

$n$, number; BMI, body mass index

Table 2. Clinical data of the ankylosing spondylitis patients

\begin{tabular}{|c|c|c|c|}
\hline & TNF- $\alpha$ treated group & $\begin{array}{c}\text { TNF- } \alpha \text { naïve } \\
\text { group }\end{array}$ & $\mathbf{p}$ \\
\hline BASDAI & $3.85 \pm 2.12$ & $3.75 \pm 1.76$ & 0.834 \\
\hline ASDAS & $2.56 \pm 1.06$ & $2.67 \pm 0.87$ & 0.653 \\
\hline BASMI & $4.09 \pm 1.88$ & $3.24 \pm 1.64$ & 0.048 \\
\hline BASFI & $3.94 \pm 2.71$ & $3.07 \pm 2.40$ & 0.157 \\
\hline MSASSS & $36.31 \pm 12.87$ & $30.08 \pm 9.35$ & 0.024 \\
\hline
\end{tabular}

TNF- $\alpha$, tumour necrosis factor alpha; BASDAl, Bath Ankylosing Spondylitis Disease Activity Index; ASDAS, Ankylosing Spondylitis Disease Activity Index; BASMI, Bath Ankylosing Spondylitis Metrology Index; BASFI, Bath Ankylosing Spondylitis Functional Index; MSASSS, Modified Stoke Ankylosing Spondylitis Spinal Score.

Table 3. Serum levels of ESR, CRP, DKK-1, sclerostin in ankylosing spondylitis patients and healthy controls

\begin{tabular}{|c|c|c|c|}
\hline & Ankylosing spondylitis & Control & $\mathbf{p}$ \\
\hline $\mathrm{ESR}(\mathrm{mm} / \mathrm{h})$ & $14.11 \pm 10.90$ & $7.22 \pm 7.57$ & 0.006 \\
\hline $\mathrm{CRP}(\mathrm{mg} / \mathrm{L})$ & $8.30 \pm 9.00$ & $2.03 \pm 2.53$ & 0.001 \\
\hline DKK-1 $(\mathrm{ng} / \mathrm{mL})$ & $79.94 \pm 107.43$ & $273.05 \pm 157.49$ & 0.001 \\
\hline Sclerostin $(\mathrm{ng} / \mathrm{mL})$ & $24.58 \pm 22.78$ & $89.35 \pm 37.23$ & 0.001 \\
\hline
\end{tabular}

TNF- $\alpha$, Tumour necrosis factor alpha; ESR, Erythrocyte sedimentation rate; CRP, C- reactive protein; DKK-1, Dickkopf-1

Serum DKK-1 levels were significantly lower in patients with AS than in healthy controls $(79.94 \pm 107.43, v s .273 .05 \pm 157.49$ $\mathrm{ng} / \mathrm{mL} ; \mathrm{p}=0.001)$. There was no significant difference between the TNF-a treated group and the TNF- $a$ inhibitör naïve group in DKK-1 levels $(p=0.679)$.
Table 4. Serum levels of ESR, CRP, DKK-1, sclerostin in TNF- $\alpha$ treated and TNF- $\alpha$ naïve groups

\begin{tabular}{|c|c|c|c|}
\hline & TNF- $\alpha$ treated & TNF- $\alpha$ naïve & p \\
\hline $\operatorname{ESR}(\mathrm{mm} / \mathrm{h})$ & $11.57 \pm 9.81$ & $16.65 \pm 11.46$ & 0.086 \\
\hline $\mathrm{CRP}(\mathrm{mg} / \mathrm{L})$ & $7.32 \pm 7.60$ & $9.27 \pm 10.24$ & 0.377 \\
\hline DKK-1 $(\mathrm{ng} / \mathrm{mL})$ & $73.77 \pm 95.44$ & $86.11 \pm 119.31$ & 0.679 \\
\hline Sclerostin $(\mathrm{ng} / \mathrm{mL})$ & $24.77 \pm 26.60$ & $24.39 \pm 18.60$ & 0.945 \\
\hline
\end{tabular}

TNF- $\alpha$, Tumour necrosis factor alpha; ESR, Erythrocyte sedimentation rate; CRP, C- reactive protein; DKK-1, Dickkopf-1

Patients with AS had significantly lower sclerostin levels (24.58 \pm 22.78 vs. $89.35 \pm 37.23 \mathrm{ng} / \mathrm{mL} ; \mathrm{p}=0.001)$ compared with healthy controls. The mean sclerostin level was not significantly different between the TNF-a treated and naïve groups ( $p=0.945)$. Data are reported in Table 3 and Table 4.

Serum levels of DKK-1 were significantly correlated with sclerostin levels in patients with AS and healthy controls $(r=0.522, p=0.001$ for patients with AS; $r=0.791, p=0.001$ for controls). DKK-1 levels were negatively correlated with ASDAS and BASMI scores $(r=-0.256, p=0.03 ; r=-0.317$, $p=0.008$ ) (Figure 1). There was no significant correlation between DKK-1 serum levels and BASDAI, BASFI, BASRI, and mSASSS scores. There was a positive correlation between BASMI score with mSASSS in patients with AS ( $r=0.778$, $\mathrm{p}=0.001$ ). BASDAI, ASDAS, BASMI, BASFI, BASRI, and mSASSS scores did not correlate with serum sclerostin levels in patients with AS.

\section{DISCUSSION}

In our study, we demonstrated that serum levels of DKK-1 and sclerostin were significantly decreased in patients with AS. The DKK-1 levels were negatively correlated with ASDAS and BASMI scores. Clinical parameters did not correlate with serum sclerostin levels in patients with AS. Additionally, DKK-1 and sclerostin levels were similar in the TNF-a treated group and the TNF-a naïve group. Conflicting results have

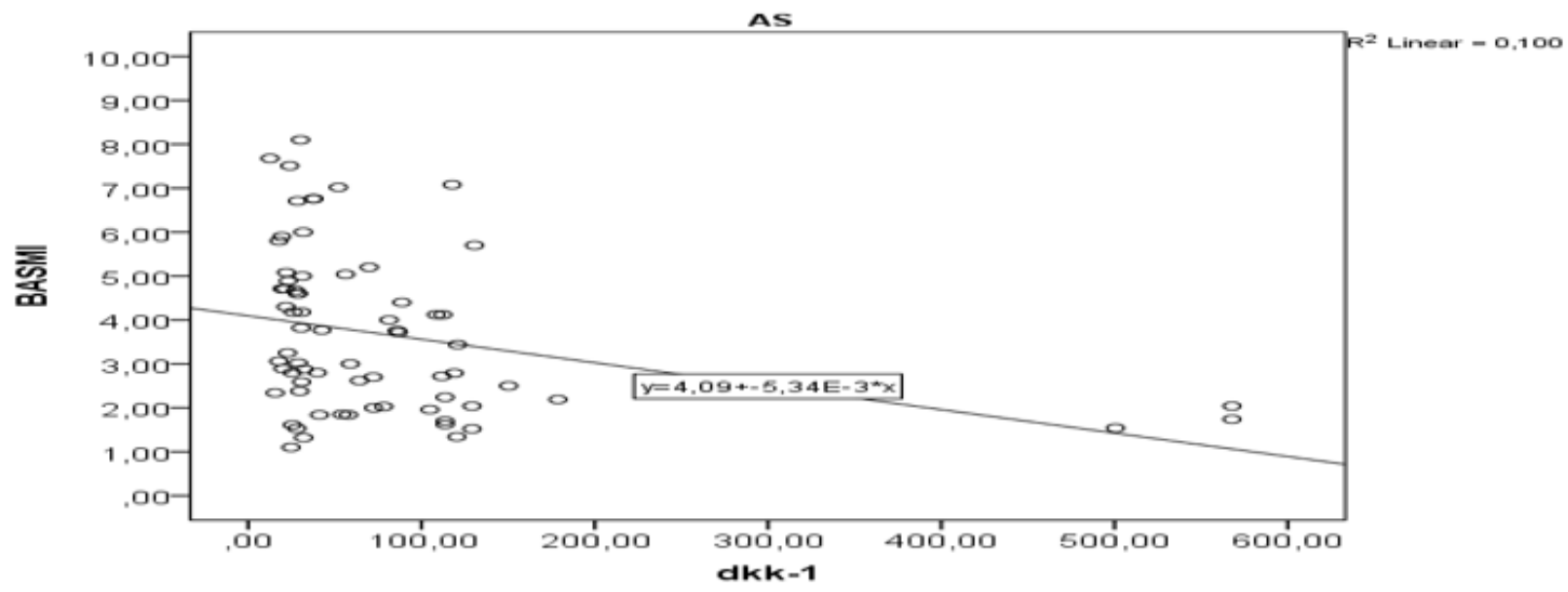

Figure 1. Inverse correlation between Dkk-1 and BASMI in AS group $(r=-0,317, p=0,008)$

AS, ankylosing spondylitis; BASMI, Bath ankylosing spondylitis metrology index; dkk-1, Dickkopf-1 
been reported in studies aiming to investigate the association between DKK-1, sclerostin, and AS symptoms, and their role in the etiopathogenesis. Diarra et al. [8] showed the role of DKK-1 in joint remodeling using a TNF-a transgenic mouse model. They found that DKK-1 levels increased in erosive joints. In their study, DKK-1 was deactivated with monoclonal antibody and this situation caused new bone formation and protected bones against structural damage. Nocturne et al. [11] evaluated 486 early axial spondyloarthropathy patients. They demonstrated that serum DKK-1 levels were significantly increased in patients with axial spondyloarthropathy compared with healthy subjects. Heiland et al. [19] examined patients with AS in the German Spondyloarthritis Inception Cohort. They reported that DKK-1 levels were significantly elevated in patients without syndesmophytes growth compared with patients with syndesmophyte growth. Huang et al. [20] reported higher levels of DKK-1 in patients with AS. Kwon et al. [12] detected lower DKK-1 levels in patients with AS, whereas Taylan et al. [21] reported similar levels of DKK-1 in patients with AS and healthy controls.

Sclerostin is expressed in bone by osteocytes, inhibits osteoblast activity by binding LRP5 / LRP6, and decreases Wnt signaling. Wnt signaling induces bone formation by stimulating osteoblast proliferation and differentiation [22]. Appel et al. [23] evaluated 46 patients with AS in their research and reported lower levels of sclerostin in these patients. Additionally, the sclerostin levels were significantly higher in patients without syndesmophyte growth than in those with syndesmophyte growth after 2 years' follow-up. Saad et al. [22] reported that patients with AS had lower levels of sclerostin. Moreover, they determined a significant increase in sclerostin levels after TNF-a blocker treatment for 12 months. Sclerostin levels were still lower in patients with AS than in healthy controls at the 12th month. Taylan et al. [21] reported similar levels of sclerostin in patients with AS and healthy controls.

TNF-a is a key pro-inflammatory cytokine in AS, which induces levels of DKK-1 and sclerostin. The association between inflammation and new bone formation in AS is not yet fully understood. TNF-a blockers, which have potent anti-inflammatory effects, cannot inhibit radiologic progression in AS [3, 4]. Daoussis et al. [10] indicated that using a TNF-a blocker increased DKK-1 levels in patients with AS. Saad et al. [22] observed patients with AS for 12 months under anti-TNF-a treatment. Sclerostin levels gradually increased in their research. On the contrary, other studies found no difference between anti-TNF-a receiving treatment groups and anti-TNF-a naïve groups [12, 21, 24].
In our study, there was no significant difference between the anti-TNF-a treated group and the anti-TNF-a naïve group in terms of DKK-1 and sclerostin levels. DKK-1 and sclerostin were not affected by TNF-a blocking agents. According to our data, the pathogenesis of radiologic damage in AS might be independent of TNF-a. Radiologic progression and inflammation might have two different uncoupled mechanisms. These two independent mechanisms may explain why TNF-a blockers might not overcome radiologic progression in AS.

Conflicting results of previous studies in DKK-1 and sclerostin levels can be explained by various reasons. The measurement methods were different in previous studies. Some studies evaluated serum total DKK-1 and sclerostin levels using classic sandwich ELISA. Others measured receptor binding functional DKK-1 and sclerostin levels. Daoussis et al. [10] reported that DKK-1 was dysfunctional in AS. Functional levels of DKK-1 and sclerostin inhibit Wnt signaling and prevent new bone formation. Although some studies reported higher levels of serum DKK-1, functional DKK-1 may be lower than total serum levels in these studies. Genetic variety may explain these contradictory results. Nocturne et al. [11] evaluated the genetic link between DKK1 and radiologic formation in patients with AS. They found no evidence of a genetic association in their cohort. Despite this, different genetic variants may affect the functions of DKK-1 and sclerostin. Although lower levels of DKK-1 and sclerostin were detected, we determined no significant correlations between DKK-1, sclerostin concentrations, and radiologic damage in AS. We did not evaluate functional levels of DKK-1 and sclerostin. This may have influenced the results. Genetic variations in our study population and sample size may also have affected our results.

In our study, serum DKK-1 and sclerostin levels were significantly lower in patients with AS. DKK-1 and sclerostin levels did not change under anti-TNF-a treatment. Sclerostin levels did not correlate with clinical parameters and radiologic damage. There was no significant correlation between DKK-1 levels and BASDAI, BASFI, BASRI, and mSASSS scores in patients with AS. Besides this, we determined a negative correlation between DKK-1 levels and ASDAS, and BASMI scores. Additionally, BASMI had a strong positive correlation with mSASSS. These results show that DKK-1 levels may be used as a predictor of disease activity and spinal mobility in patients with AS. Our results suggest that DKK-1 may be involved in the pathogenetic mechanisms of radiologic progression in AS. 
One of the limitations of our study was its moderate sample size. Although DKK-1 level was not affected by sociodemographic data, there was a significant difference in sex and BMI between patients with AS and the control group [11]. We had no data about pre-treatment levels of DKK-1 and sclerostin. Functional levels of DKK-1 and sclerostin were not evaluated in our study. HLA-B27 positivity or negativity were not included in our data.

In conclusion, an alteration of DKK-1 and sclerostin was determined in patients with AS. Our results support the hypothesis that DKK-1 and sclerostin levels are decreased in AS. DKK-1 and sclerostin might play a role in the pathogenetic mechanisms of new bone formation and structural damage in AS. Wnt / $\beta$-catenin signaling has also been demonstrated in the apoptosis of osteoblastic cells. Sclerostin may reduce bone formation by inhibiting the terminal differentiation of osteoblasts and may induce their apoptosis. Sclerostin may induce expression of the proapoptotic factor Bax and caspases 1, 3, 4, and 7, which are the hallmarks of an apoptotic response [25,26]. DKK-1 and sclerostin levels are resistant to anti-TNF-a agents. Therefore, radiologic progression and inflammation may be two uncoupled cycles in patients with AS. Inflammation starts at the beginning of the disease. Following the inflammatory process, a repair mechanism emerges for new bone formation. If an anti-TNF-a agent is started after a repair tissue is already present, it may be too late to affect the process of new bone formation. Inflammation may trigger the radiologic damage but a different and independent mechanism may sustain the progression. If this mechanism is correct, early use of anti-TNF-a agents may result in a retardation of new bone formation. TNF-a blockers reduce the inflammation and disease activity in resistant forms of AS. On the other hand, different treatment strategies should be added to current treatment methods to prevent new bone formation and radiographic progression in AS. As the underlying mechanisms of radiologic progression are elucidated, new treatment strategies will develop.

\section{DECLARATION OF CONFLICT OF INTEREST}

The authors declared no conflicts of interest with respect to the authorship and/or publication of this article. This study received a grant from the Gaziantep University Scientific Research Project Unit (Project no: TF.15.34).

\section{REFERENCES}

1. Schett G. Bone formation versus bone resorption in ankylosing spondylitis. Adv Exp Med Biol 2009; 649: 114 21.
2. Braun J, Baraliakos X. Imaging of axial spondyloarthritis including ankylosing spondylitis. Ann Rheum Dis 2011; 70: 97-103.

3. van der Heijde D, Landewe $R$, Baraliakos $X$, et al. Radiographic findings following two years of infliximab therapy in patients with ankylosing spondylitis. Arthritis Rheum 2008; 58: 3063-70.

4. van der Heijde D, Landewe $\mathrm{R}$, Einstein $\mathrm{S}$, et al. Radiographic progression of ankylosing spondylitis after up to two years of treatment with etanercept. Arthritis Rheum 2008; 58: 1324-31.

5. Daoussis D, Andonopoulos AP. The emerging role of Dickkopf-1 in bone biology: is it the main switch controlling bone and joint remodeling? Semin Arthritis Rheum 2011; 41: 170-7.

6. Klavdianou K, Liossis SN, Sakkas L, Daoussis D. The role of Dickkopf-1 in joint remodeling and fibrosis: A link connecting spondyloarthropathies and scleroderma? Semin Arthritis Rheum 2017; 46: 430-8.

7. Haynes KR, Pettit AR, Duan R, Tseng HW, et al. Excessive bone formation in a mouse model of ankylosing spondylitis is associated with decreases in Wnt pathway inhibitors. Arthritis Res Ther 2012; 14: R253.

8. Diarra D, Stolina M, Polzer K, et al. Dickkopf-1 is a master regulator of joint remodeling. Nat Med 2007; 13: 156-63.

9. Senolt L, Hulejova $\mathrm{H}$, Krystufkova $\mathrm{O}$, et al. Low circulating Dickkopf-1 and its link with severity of spinal involvement in diffuse idiopathic skeletal hyperostosis. Ann Rheum Dis 2012; 71: 71-4.

10. Daoussis D, Liossis SNC, Solomou EE, et al. Evidence that Dkk-1 is dysfunctional in ankylosing spondylitis. Arthritis Rheum 2010; 62: 150-8.

11. Nocturne G, Pavy S, Boudaoud $S$, et al. Increase in Dickkopf-1 serum level in recent spondyloarthritis. Data from the DESIR cohort. PLoS One 2015; 10: e0134974.

12. Kwon SR, Lim MJ, Suh CH, et al. Dickkopf-1 level is lower in patients with ankylosing spondylitis than in healthy people and is not influenced by anti tumor necrosis factor therapy. Rheumatol Int 2012; 32: 2523-7.

13. Van Der Linden S, Valkenburg HA, Cats A. Evaluation of diagnostic criteria for ankylosing spondylitis. A proposal for modification of the New York criteria. Arthritis Rheum 1984; 27: 361-8. 
14. Akkoc Y, Karatepe AG, Akar S, Kirazli Y, Akkoc N. A Turkish version of the Bath Ankylosing Spondylitis Disease Activity Index: reliability and validity. Rheumatology international 2005; 25: 280-4.

15. Pedersen SJ, Sørensen IJ, Hermann KG, et al. Responsiveness of the Ankylosing Spondylitis Disease Activity Score (ASDAS) and clinical and MRI measures of disease activity in a 1-year follow-up study of patients with axial spondyloarthritis treated with tumour necrosis factor alpha inhibitors. Ann Rheum Dis 2010; 69: 1065-71.

16. Calin A, Garrett S, Whitelock H, et al. A new approach to defining functional ability in ankylosing spondylitis: the development of the Bath Ankylosing Spondylitis Functional Index. J Rheumatol 1994; 21: 2281-5.

17. Calin A, Mackay K, Santos H, Brophy S. A new dimension to outcome: application of the Bath Ankylosing Spondylitis Radiology Index. J Rheumatol 1999; 26: 98892.

18. Creemers MC, Franssen MJ, van't Hof MA, Gribnau FW, van de Putte LB, van Riel PL. Assessment of outcome in ankylosing spondylitis: an extended radiographic scoring system. Ann Rheum Dis 2005; 64: 127-9.
19. Heiland GR, Appel H, Poddubnyy D, et al. High level of functional dickkopf-1 predicts protection from syndesmophyte formation in patients with ankylosing spondylitis. Ann Rheum Dis 2012; 71: 572-4.

20. Huang J, Song G, Yin Z, Fu Z, Ye Z. Alteration of Bone Turnover Markers in Canonical Wingless Pathway in Patients With Ankylosing Spondylitis. Arch Rheumatol 2016; 31: 221-8.

21. Taylan A, Sari I, Akinci B, et al. Biomarkers and cytokines of bone turnover: extensive evaluation in a cohort of patients with ankylosing spondylitis. BMC Musculoskelet Disord 2012; 13: 191.

22. Saad CG, Ribeiro AC, Moraes JC, et al. Low sclerostin levels: a predictive marker of persistent inflammation in ankylosing spondylitis during anti-tumor necrosis factor therapy? Arthritis Res Ther 2012; 14: R216.

23. Appel H, Ruiz-Heiland G, Listing J, et al. Altered skeletal expression of sclerostin and its link to radiographic progression in ankylosing spondylitis. Arthritis Rheum 2009; 60: 3257-62.

24. Ustun N, Tok F, Kalyoncu U, et al. Sclerostin and Dkk-1 in patients with ankylosing spondylitis. Acta Reumatol Port 2014: 39; 146-51. 